\title{
Improvement of Flavonoids in Lemon Seeds on Oxidative Damage of Human Embryonic Kidney 293T Cells Induced by $\mathrm{H}_{2} \mathrm{O}_{2}$
}

\author{
Dingyi Yang, ${ }^{1}$ Yong Jiang, ${ }^{1}$ Yuqing Wang, ${ }^{1}$ Qianqian Lei $\left(\mathbb{D},{ }^{1}\right.$ Xin Zhao $\mathbb{D},{ }^{2}$ Ruokun Yi, \\ and Xin Zhang $\mathbb{1}^{3}$ \\ ${ }^{1}$ Key Laboratory for Biorheological Science and Technology of Ministry of Education (Chongqing University), Chongqing University \\ Cancer Hospital \& Chongqing Cancer Institute \& Chongqing Cancer Hospital, Chongqing 400044, China \\ ${ }^{2}$ Chongqing Collaborative Innovation Center for Functional Food, Chongqing Engineering Research Center of Functional Food, \\ Chongqing Engineering Laboratory for Research and Development of Functional Food, Chongqing University of Education, \\ Chongqing 400067, China \\ ${ }^{3}$ Chongqing Key Laboratory of Translational Research for Cancer Metastasis and Individualized Treatment, Chongqing University \\ Cancer Hospital \& Chongqing Cancer Institute \& Chongqing Cancer Hospital, Chongqing 400030, China
}

Correspondence should be addressed to Xin Zhang; cqres@foxmail.com

Received 7 February 2020; Revised 22 March 2020; Accepted 4 April 2020; Published 20 April 2020

Guest Editor: German Gil

Copyright (C) 2020 Dingyi Yang et al. This is an open access article distributed under the Creative Commons Attribution License, which permits unrestricted use, distribution, and reproduction in any medium, provided the original work is properly cited.

\begin{abstract}
In this study, flavonoids in lemon seeds (FLS) were used to assess its improvement on the oxidative damage of human embryonic kidney $293 \mathrm{~T}$ cells (HEK 293T cells) induced by $\mathrm{H}_{2} \mathrm{O}_{2}$. In vitro experiments showed that the survival rates of $\mathrm{HEK} 293 \mathrm{~T}$ cells treated with different flavonoid concentrations $(50 \mu \mathrm{g} / \mathrm{mL}, 100 \mu \mathrm{g} / \mathrm{mL}$, and $150 \mu \mathrm{g} / \mathrm{mL})$ exceeded $95 \%$, indicating no significant toxic effect. Compared with the normal group, $\mathrm{H}_{2} \mathrm{O}_{2}(0.3 \mathrm{mmol} / \mathrm{L})$ resulted significantly in oxidative stress injury of HEK $293 \mathrm{~T}$ cells. The survival rate of the damaged cells increased after treatment with flavonoids, and the survival rate of cells treated with a high concentration $(150 \mu \mathrm{g} / \mathrm{mL})$ of flavonoids was $76.2 \%$. Flavonoids also effectively inhibited $\mathrm{H}_{2} \mathrm{O}_{2}$-induced apoptosis. At the same time, flavonoid treatment significantly reduced the malondialdehyde content in cells and increased the levels of catalase (CAT), superoxide dismutase (SOD), glutathione (GSH), and glutathione peroxidase (GSH-Px). Quantitative polymerase chain reaction (qPCR) and Western blot analysis also suggested that FLS upregulated mRNA and protein expressions of CAT, SOD (SOD1, SOD2), GSH (GSH1), and GSH-Px in $\mathrm{H}_{2} \mathrm{O}_{2}$-induced oxidative damage of HEK 293T cells. The high-performance liquid chromatography analysis demonstrated that FLS contained six compounds, including gallocatechin, caffeic acid, epicatechin, vitexin, quercetin, and hesperidin. FLS were proven to have a good antioxidant capacity in vitro and improve significantly the oxidative damage of HEK 293T cells induced by $\mathrm{H}_{2} \mathrm{O}_{2}$. The biological activity value warrants investigation in additional studies.
\end{abstract}

\section{Introduction}

Citrus limon (L.) Burm. f. has been widely consumed as a vitamin-rich fruit [1]. Most of the lemon seeds in the fruit are discarded. In traditional Chinese medicine, only a small amount of lemon seeds is added in some compounds in traditional Chinese medicines. Little is known regarding its biological activity in modern molecular biology and other technologies. One study has shown that lemon seed extract can play an antioxidant role in soybean oil processing [2]. Lemon seed extract can maintain oxidation stability and $\alpha$ tocopherol in soybean oil processing [3]. In vitro experiments have demonstrated that lemon seed extract can inhibit the proliferation of human breast cancer and play an anticancer role [4].

Reactive oxygen species (ROS) produced by human aerobic metabolism mainly include superoxide anion $\left(\mathrm{O}_{2}{ }^{-}\right)$, peroxy anion $\left(\mathrm{O}_{2}{ }^{2-}\right)$, hydroxyl radical $(\cdot \mathrm{OH})$, organic peroxy radical $\left(\mathrm{ROO}^{-}\right)$, and $\mathrm{H}_{2} \mathrm{O}_{2}$. When the amount of oxygen free radical (OFR) exceeds the range of its own antioxidant protection system and excessive oxidation occurs, it will attack human cells to obtain electrons and maintain its own stability, leading to damage relative to the conformation and the function of cells, as well as inflammation and other types of 
chronic diseases, such as cardiovascular diseases, nervous system diseases, kidney diseases, and cancer $[5,6]$. The mechanisms of these diseases, for the most part, involve oxidative changes of key physiological molecules, such as regulation of proteins, lipids, carbohydrates, nucleic acids, gene expression, and inflammatory response [7]. To protect the body from damage of OFR, humans resist oxidative stress through their own antioxidant system and intake of exogenous antioxidants. The enzyme system includes superoxide dismutase (SOD), catalase (CAT), and the glutathione peroxidase (GSH-Px) system. Nonenzymatic antioxidants include gluten, tea polyphenols, tocopherols, flavonoids, and fatty acids [8]. As the main form of ROS in vivo, $\mathrm{H}_{2} \mathrm{O}_{2}$, with a wide range of sources and stable properties, can produce $\cdot \mathrm{OH}$ with intracellular $\mathrm{Fe}^{2+}$ via the Fenton reaction, thus causing a chain reaction, which is a preferred inducer for cell oxidative stress modeling [9].

293T cell is a human renal epithelial cell line, which exhibits an obvious influence on the external environment and strong protein expression. It is often used to examine the inhibition effect of oxidative stress of the test sample [10]. Renal epithelial cell damage is closely related to chronic renal diseases, such as chronic pyelonephritis and chronic obstructive nephropathy [11]. The damage of renal epithelial cells will lead to the decline of renal function and will also affect other diseases, including myeloma, leukemia, and malignant tumor [12]. Human embryonic kidney 293T can effectively detect the role of active substances in disease control through oxidative stress. Therefore, this study investigated the antioxidant activity of flavonoids in vitro and established an HEK 293T cell injury model using $\mathrm{H}_{2} \mathrm{O}_{2}$ as an inducer. Besides, the protective effect of different concentrations of flavonoids on cells with oxidative stress injury was evaluated. At the same time, the active components of flavonoids were determined, which provided reference for flavonoids to treat related diseases caused by oxidative stress.

\section{Materials and Methods}

2.1. Preparation for Extracts of Flavonoids from Lemon Seeds (FLS). The extracts of FLS (Chongqing Huida Lemon Technology Group Co., Ltd, Chongqing, China) were dried to maintain a constant weight of lemon seeds, were ground in a mortar, and were sieved to obtain lemon seed powder. The powder was degreased with n-hexane for $90 \mathrm{~min}$ (degreasing temperature, $50^{\circ} \mathrm{C}$; material liquid ratio, 1:30; and power, $200 \mathrm{~W})$. After filtration and drying, flavonoids were extracted from $8 \mathrm{~g}$ of degreased lemon seed powder with $300 \mathrm{~mL}$ of $95 \%$ ethanol for $60 \mathrm{~min}$ (temperature, $50^{\circ} \mathrm{C}$; power, $200 \mathrm{~W})$. Finally, the sample solution was obtained by filtration and the dry FLS were evaporated using a rotary evaporator (Great Wall R-1050, Zhengzhou Greatwall Scientific Industrial and Trade Co., Ltd., Zhengzhou, Henan, China).

2.2. Cell Culture. Human embryonic kidney (HEK) 293T cells (Shanghai Institute of Biochemistry and Cell Biology, Shanghai, China) were resuscitated from liquid nitrogen and seeded in Dulbecco's Modified Eagle's Medium (DMEM) (high sugar, containing 10\% fetal bovine serum and $1 \%$ penicillin-streptomycin double antibody solution) (Solarbio Life Sciences, Beijing, China). The medium was changed two or three times a week in a saturated humid environment at $37^{\circ} \mathrm{C}$ and $5 \% \mathrm{CO}_{2}$. When the cell fusion reached $90 \%$, trypsin (0.25\%) (Solarbio Life Sciences) was used for digestion and passage. The cells in the logarithmic phase were used in all of the experiments.

2.3. Toxicity of FLS on HEK 293T Cells. HEK 293T cell suspension $\left(1 \times 10^{4}\right.$ cells $\left./ \mathrm{mL}\right)$ was seeded into a 96-well cell culture plate ( $60 \mu \mathrm{L}$ cells $+100 \mu \mathrm{L}$ culture medium), cultured at $37^{\circ} \mathrm{C}$ for $24 \mathrm{~h}$ until it adhered to the wall, and $20 \mu \mathrm{L}$ of FLS solution with different concentrations (normal group, $50 \mu \mathrm{g} / \mathrm{mL}, 100 \mu \mathrm{g} / \mathrm{mL}$, and $150 \mu \mathrm{g} / \mathrm{mL}$ ) was added to the culture.

2.4. Detection of Cell Survival Rate by MTT. The MTT method was used to determine cell survival rate: HEK 293T cells were initially cultured on the wall for $24 \mathrm{~h}$, with $20 \mu \mathrm{L}$ of FLS solution and with different concentrations (normal group, $50 \mu \mathrm{g} / \mathrm{mL}, 100 \mu \mathrm{g} / \mathrm{mL}$, and $150 \mu \mathrm{g} / \mathrm{mL}$ ) for $24 \mathrm{~h}$; $20 \mu \mathrm{L}$ of MTT ( $5 \mathrm{mg} / \mathrm{mL}$ ) (Solarbio Life Sciences) was added, mixed, and cultured for $4 \mathrm{~h}$. The upper medium was discarded, followed by adding $150 \mu \mathrm{L}$ of dimethyl sulfoxide (DMSO) (Solarbio Life Sciences), shaking for $30 \mathrm{~min}$ in dark period and at $37^{\circ} \mathrm{C}$. Optical density (OD) was measured at $490 \mathrm{~nm}$. The experiment was performed in triplicate. Cell survival rate $(\%)=(\mathrm{Ar} / \mathrm{As}) \times 100 \%$, where $\mathrm{Ar}$ is OD of the FLS treatment group and As is OD of the normal group (Evolution $^{\mathrm{TM}}$ 350, Thermo Fisher Scientific, New York, USA).

2.5. Observation of Cell Proliferation. HEK 293T cell suspension $\left(1 \times 10^{4}\right.$ cells $\left./ \mathrm{mL}\right)$ was seeded into a 96-well cell culture plate $(60 \mu \mathrm{L}$ cells $+100 \mu \mathrm{L}$ culture medium $)$, cultured at $37^{\circ} \mathrm{C}$ for $24 \mathrm{~h}$, adhered to the wall, and cultured with $20 \mu \mathrm{L}$ of $\mathrm{H}_{2} \mathrm{O}_{2}(0.3 \mathrm{mmol} / \mathrm{L})$, and $20 \mu \mathrm{L}$ of FLS solution with different concentrations (normal group, $40 \mu \mathrm{g} / \mathrm{mL}$, $100 \mu \mathrm{g} / \mathrm{mL}$, and $160 \mu \mathrm{g} / \mathrm{mL}$ ) was added to the culture for $24 \mathrm{~h}$, and the cell survival rate was measured using the MTT method (Figure 1(a)).

HEK 293T cell suspension $\left(1 \times 10^{4}\right.$ cells $\left./ \mathrm{mL}\right)$ was seeded into a 96-well cell culture plate ( $60 \mu \mathrm{L}$ cells $+100 \mu \mathrm{L}$ culture medium), cultured at $37^{\circ} \mathrm{C}$ for $24 \mathrm{~h}$, adhered to the wall, and cultured with $20 \mu \mathrm{L}$ of $\mathrm{H}_{2} \mathrm{O}_{2}(0.3 \mathrm{mmol} / \mathrm{L})$ for $4 \mathrm{~h}$ to prepare the oxidative damage model. After discarding the upper medium, $20 \mu \mathrm{L}$ of FLS solution with different concentrations (normal group, $40 \mu \mathrm{g} / \mathrm{mL}, 100 \mu \mathrm{g} / \mathrm{mL}$, and $160 \mu \mathrm{g} / \mathrm{mL}$ ) was added to the culture for $24 \mathrm{~h}$, and the cell survival rate was measured using the MTT method (Figure 1(b)).

2.6. Observation of Apoptosis by Flow Cytometry. HEK 293T cells were treated according to the cell proliferation experiment, collected, and formed into single cell suspension. After fixing and staining, apoptosis was detected using flow cytometry (Accuri C6, BD Biosciences, San Jose, CA, USA).

2.7. Determinations of Malondialdehyde (MDA), SOD, GSH, GSH-Px, and CAT in HEK 293 T Cells. HEK 293T cells in logarithmic growth phase were digested with $0.25 \%$ trypsin, seeded in a six-well cell culture plate $\left(1 \times 10^{5}\right.$ cells $\left./ \mathrm{mL}\right)$, 


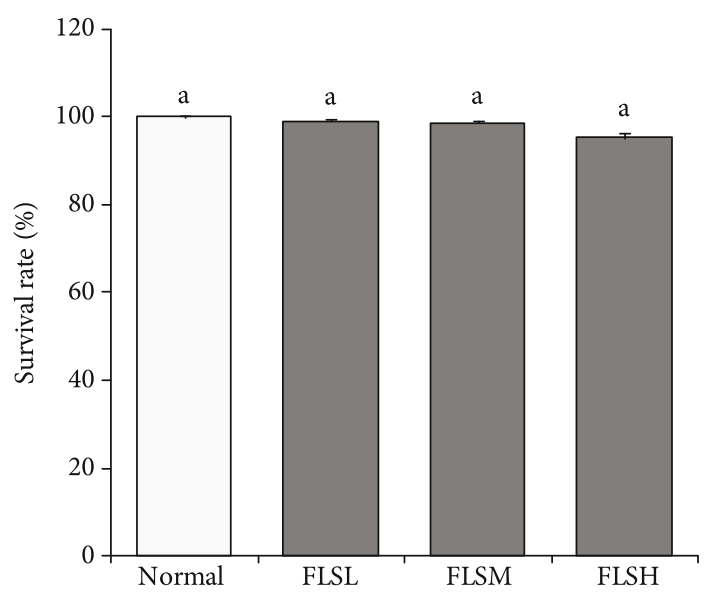

FiguRE 1: Effect of treatment with flavonoids of lemon seeds (FLS) on the survival rate of human embryonic kidney $293 \mathrm{~T}$ cells. Values presented are the mean \pm standard deviation $\left(N=6\right.$ /group). ${ }^{\mathrm{a}-\mathrm{e}}$ Mean values with different letters over the bar are significantly different $(P<0.05)$ according to Tukey's honestly significant difference. Normal: untreated HEK 293T cells; FLSL: $50 \mu \mathrm{g} / \mathrm{mL}$ of FLS-treated HEK 293T cells; FLSM: $100 \mu \mathrm{g} / \mathrm{mL}$ of FLS-treated HEK 293T cells; FLSH: $150 \mu \mathrm{g} / \mathrm{mL}$ of FLS-treated HEK 293T cells.

cultured with $2 \mathrm{~mL}$ of DMEM in a saturated humid environment at $37^{\circ} \mathrm{C}$ and $5 \% \mathrm{CO}_{2}$ for $24 \mathrm{~h}$, adhered to the wall, with the addition of $200 \mu \mathrm{L}$ of $\mathrm{H}_{2} \mathrm{O}_{2}(0.3 \mathrm{mmol} / \mathrm{L})$, mixed well, and cultured for $4 \mathrm{~h}$ to prepare the oxidative damage model. FLS aqueous extract $(200 \mu \mathrm{L})$ with different concentrations $(0 \mu \mathrm{g} / \mathrm{mL}, 50 \mu \mathrm{g} / \mathrm{mL}, 100 \mu \mathrm{g} / \mathrm{mL}$, and $150 \mu \mathrm{g} / \mathrm{mL})$ was added into each well of the HEK $293 \mathrm{~T}$ cell model of oxidative damage, and PBS solution $(0.1 \mathrm{~mol} / \mathrm{L})$ was added to maintain balance. The cells were further cultured at $37^{\circ} \mathrm{C}$ and $5 \% \mathrm{CO}_{2}$ for $24 \mathrm{~h}$. HEK $293 \mathrm{~T}$ cells treated with FLS were removed from the old culture medium, washed with precooled PBS, detached from the wall with $200 \mu \mathrm{L}$ of trypsin, transferred to a $1.5 \mathrm{~mL}$ centrifuge tube, and centrifuged to discard the supernatant. The cells were again washed with precooled PBS and centrifuged at $4,000 \mathrm{r} / \mathrm{min}$ for $15 \mathrm{~min}$ to discard the supernatant, with the addition of $800 \mu \mathrm{L}$ normal saline, and homogenized. The content of MDA, SOD, GSH, GSH$\mathrm{Px}$, and CAT in the homogenate was determined according to the kit instructions (Nanjing Jiancheng Bioengineering Institute, Nanjing City, China).

2.8. Clonogenic Assay. The HEK $293 \mathrm{~T}$ cells were cultured according to the cell culture method in Section 2.2; the HEK 293T cells in the logarithmic growth stage were digested by $2.5 \mathrm{~g} / \mathrm{L}$ trypsin to form a single cell suspension. The HEK 293T cells were inoculated into 24-well plates, with 50 cells per well. Each group of cells was inoculated with six wells, five groups in total (normal, control, FLSL, FSLM, and FLSH groups). HEK 293T cells in the normal group were cultured for 1 week without any other treatment. HEK 293T cells in the control group were cultured using $900 \mu \mathrm{L}$ DMEM culture medium and $100 \mu \mathrm{L}$ culture medium solution containing $\mathrm{H}_{2} \mathrm{O}_{2}(0.3 \mathrm{mmol} / \mathrm{L})$; the FLSL group, FSLM group, and FLSH group were cultured using $800 \mu \mathrm{L}$ DMEM culture medium, $100 \mu \mathrm{L}$ culture medium solution containing $\mathrm{H}_{2} \mathrm{O}_{2}(0.3 \mathrm{mmol} / \mathrm{L})$, and $100 \mu \mathrm{L}$ culture medium solution containing FLS $(40 \mu \mathrm{g} / \mathrm{mL}, 80 \mu \mathrm{g} / \mathrm{mL}$, and $160 \mu \mathrm{g} / \mathrm{mL}$ ) for 1 week. The culture medium was discarded, the wells of the culture dish were washed using
PBS, fixed with $1 \mathrm{~mL}$ pure methanol for $15 \mathrm{~min}$, and Giemsa stain solution (Solarbio Life Sciences) was used for dyeing. The number of clones comprising more than 50 cells was counted when the culture plate was placed in the low multiple of microscope (IX73, Olympus, Tokyo, Japan), and the clone formation rate was calculated according to the following formula: clone formation rate $(\%)=$ clone number/inoculation number $\times 100 \%$ [13] .

\subsection{Quantitative Polymerase Chain Reaction ( $q P C R)$. HEK} 293T cells were cultured into a six-well plate $\left(1 \times 10^{5}\right.$ cells $/ \mathrm{mL}$ ) and treated with FLS at different concentrations after modeling. The total RNA of HEK 293T cells was extracted using the TRIzol Reagent (Thermo Fisher Scientific). We added $1 \mu \mathrm{L}$ of Oligo (dT) 18 primer (500 ng) and $1.0 \mu \mathrm{L}$ of total RNA $(1.0 \mu \mathrm{g})$ to $10.0 \mu \mathrm{L}$ of nonnuclease water heated at $65^{\circ} \mathrm{C}$ for $5 \mathrm{~min}$ on a gradient PCR apparatus. Then, the mixture containing $4.0 \mu \mathrm{L}$ of $5 \mathrm{x}$ reaction buffer, $1.0 \mu \mathrm{L}$ of RiboLock RNase Inhibitor $(20 \mathrm{U}), 2.0 \mu \mathrm{L}$ of $10 \mathrm{mM}$ dNTP Mix, and $1.0 \mu \mathrm{L}$ of RevertAid Reverse Transcriptase $(200 \mathrm{U} / \mu \mathrm{L})$ (Thermo Fisher Scientific) was added to the total RNA system, which was transcribed into cDNA at $42^{\circ} \mathrm{C}$ for $60 \mathrm{~min}$ and $70^{\circ} \mathrm{C}$ for $5 \mathrm{~min}$. Amplification conditions were as follows: denaturation at $95^{\circ} \mathrm{C}$ for $3 \mathrm{~min}$, annealing at $60^{\circ} \mathrm{C}$ for $30 \mathrm{~s}$, extension at $95^{\circ} \mathrm{C}$ for $1 \mathrm{~min}$, and a total of 40 cycles. mRNA expressions of SOD, CAT, GSH, and GSHPx were detected using qPCR (Table 1). cDNA of each gene was amplified three times in parallel, and the mean of Ct was obtained. The housekeeping gene GAPDH was used as an internal reference, and related genes were calculated according to $2^{-\Delta \Delta \mathrm{Ct}}$ (StepOnePlus, Thermo Fisher Scientific) [14].

2.10. Western Blot. After cell lysis using RIPA cell lysis buffer, the supernatant was isolated, in which the protein concentration was measured using a protein detection kit. We isolated $30-50 \mu \mathrm{g}$ protein by SDS-PAGE, and we electroimprinted it onto a nitrocellulose (NC) membrane. The NC membrane was sealed and, in turn, bound with primary antibodies and secondary antibodies of SOD1, SOD2, GSH1, and CAT, 
TABLE 1: Sequences of reverse transcription-polymerase chain reaction primers.

\begin{tabular}{|c|c|c|}
\hline Accession number & Gene name & Sequence \\
\hline NM_000454.4 & $S O D$ & $\begin{array}{l}\text { Forward: 5'-AGATGGTGTGGCCGATGTGT-3' } \\
\text { Reverse: } 5^{\prime} \text {-TCCAGCGTTTCCTGTCTTTGTA-3' }\end{array}$ \\
\hline NM_001752.3 & CAT & $\begin{array}{l}\text { Forward: 5'-TGTTGCTGGAGAATCGGGTTC-3' } \\
\text { Reverse: } 5^{\prime} \text {-TCCCAGTTACCATCTTCTGTGTA-3' }\end{array}$ \\
\hline NM_000178.4 & GSH & $\begin{array}{l}\text { Forward: 5' -TACGGCTCACCCAATGCTC-3' } \\
\text { Reverse: } 5^{\prime} \text {-CTATGGCACGCTGGTCAAATA-3' }\end{array}$ \\
\hline NM_201397.2 & $G S H-P x$ & $\begin{array}{l}\text { Forward: 5'-GTCGGTGTATGCCTTCTCGG-3' } \\
\text { Reverse: } 5^{\prime} \text {-CTGCAGCTCGTTCATCTGGG-3' }\end{array}$ \\
\hline NM_002046.7 & GAPDH & $\begin{array}{l}\text { Forward: } 5^{\prime} \text {-TCAAGAAGGTGGTGAAGCAGG-3' } \\
\text { Reverse: } 5^{\prime} \text {-AGCGTCAAAGGTGGAGTG-3' }\end{array}$ \\
\hline
\end{tabular}

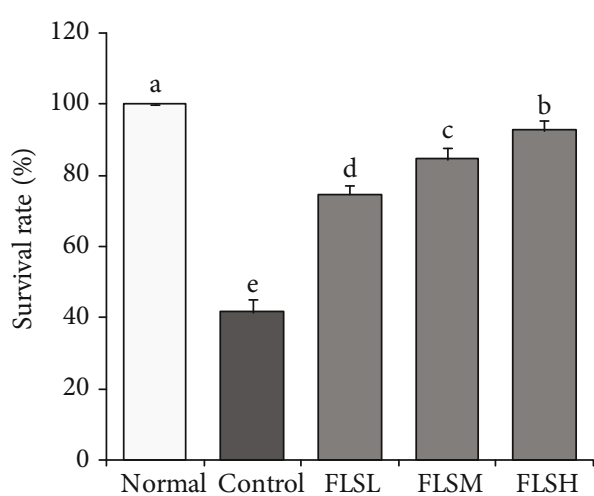

(a)

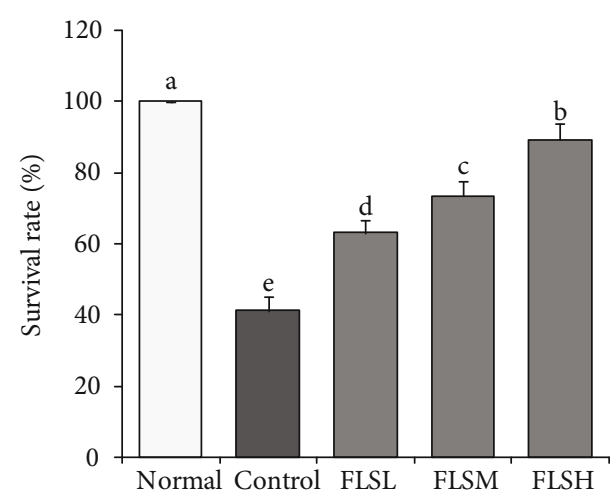

(b)

Figure 2: Effect of flavonoids of lemon seeds (FLS) on the survival rate of $\mathrm{H}_{2} \mathrm{O}_{2}$-damaged human embryonic kidney 293T cells. (a) Simultaneous treatment with $\mathrm{H}_{2} \mathrm{O}_{2}$ and FLS; (b) treatment with FLS after $\mathrm{H}_{2} \mathrm{O}_{2}$-induced oxidative damage. ${ }^{\text {a-e }}$ Mean values with different letters over the bar are significantly different $(P<0.05)$ according to Tukey's honestly significant difference. Normal: untreated HEK $293 \mathrm{~T}$ cells; FLSL: $50 \mu \mathrm{g} / \mathrm{mL}$ of FLS-treated HEK 293T cells; FLSM: $100 \mu \mathrm{g} / \mathrm{mL}$ of FLS-treated HEK 293T cells; FLSH: $150 \mu \mathrm{g} / \mathrm{mL}$ of FLS-treated HEK 293T cells.

and the antibody (Thermo Fisher Scientific) binding zone was detected using chemiluminescence (Tanon Science and Technology Co., Ltd., Shanghai, China) [15].

2.11. High-Performance Liquid Chromatography (HPLC). The FLS extracts were dissolved in DMSO to obtain a solution with a concentration of $10 \mathrm{mg} / \mathrm{mL}$, and then diluted with $50 \%$ methanol to obtain a final concentration of $2 \mathrm{mg} / \mathrm{mL}$. After passing through a $0.22 \mu \mathrm{m}$ organic filter membrane, the solution was tested with an injection volume of $5 \mu \mathrm{L}$. The data were as follows: chromatographic column: Accucore C18 column $(2.6 \mu \mathrm{m}, 4.6 \mathrm{~mm} \times 150 \mathrm{~mm})$; mobile phase A: $0.5 \%$ acetic acid; mobile phase $\mathrm{B}$ : acetonitrile; flow rate: $0.6 \mathrm{~mL} / \mathrm{min}$; column temperature: $35^{\circ} \mathrm{C}$; detection wavelength: $285 \mathrm{~nm}$; gradient elution conditions: 0-10 min, $12 \%-25 \%$ A; $10-30 \mathrm{~min}, 25 \%-45 \% \mathrm{~B}$.

2.12. Statistics. SPSS 20.0 statistical software was used to analyze the data. All of the experimental data were repeated three times. The results are expressed as mean \pm standard deviation values. The results were analyzed using Duncan's multirange test and one-way analysis of variance. A $P<0.05$ was considered to be statistically significant.

\section{Results}

3.1. Toxicity of FLS on HEK 293T Cells. As shown in Figure 1, after treatment by $50 \mu \mathrm{g} / \mathrm{mL}, 100 \mu \mathrm{g} / \mathrm{mL}$, and $150 \mu \mathrm{g} / \mathrm{mL}$ of FLS extracts, the survival rates of HEK 293T cells exceeded $95 \%$, indicating no significant lethal effect of FLS within this range $(0-150 \mu \mathrm{g} / \mathrm{mL})$ on HEK $293 \mathrm{~T}$ cells. Therefore, FLS extracts from lemon seed with concentrations of $50 \mu \mathrm{g} / \mathrm{mL}, 100 \mu \mathrm{g} / \mathrm{mL}$, and $150 \mu \mathrm{g} / \mathrm{mL}$ were used in the subsequent studies.

3.2. Protective Effect of FLS on Proliferation of $\mathrm{H}_{2} \mathrm{O}_{2}$-Induced HEK 293 T Cells. As shown in Figure 2, compared with normal cells, the survival rate of HEK 293T cells injured by $\mathrm{H}_{2} \mathrm{O}_{2}$ decreased significantly. After simultaneous treatment with $\mathrm{H}_{2} \mathrm{O}_{2}$ (Figure 2(a)) and after $\mathrm{H}_{2} \mathrm{O}_{2}$-induced oxidative damage (Figure 2(b)), the survival rates of the cells treated 

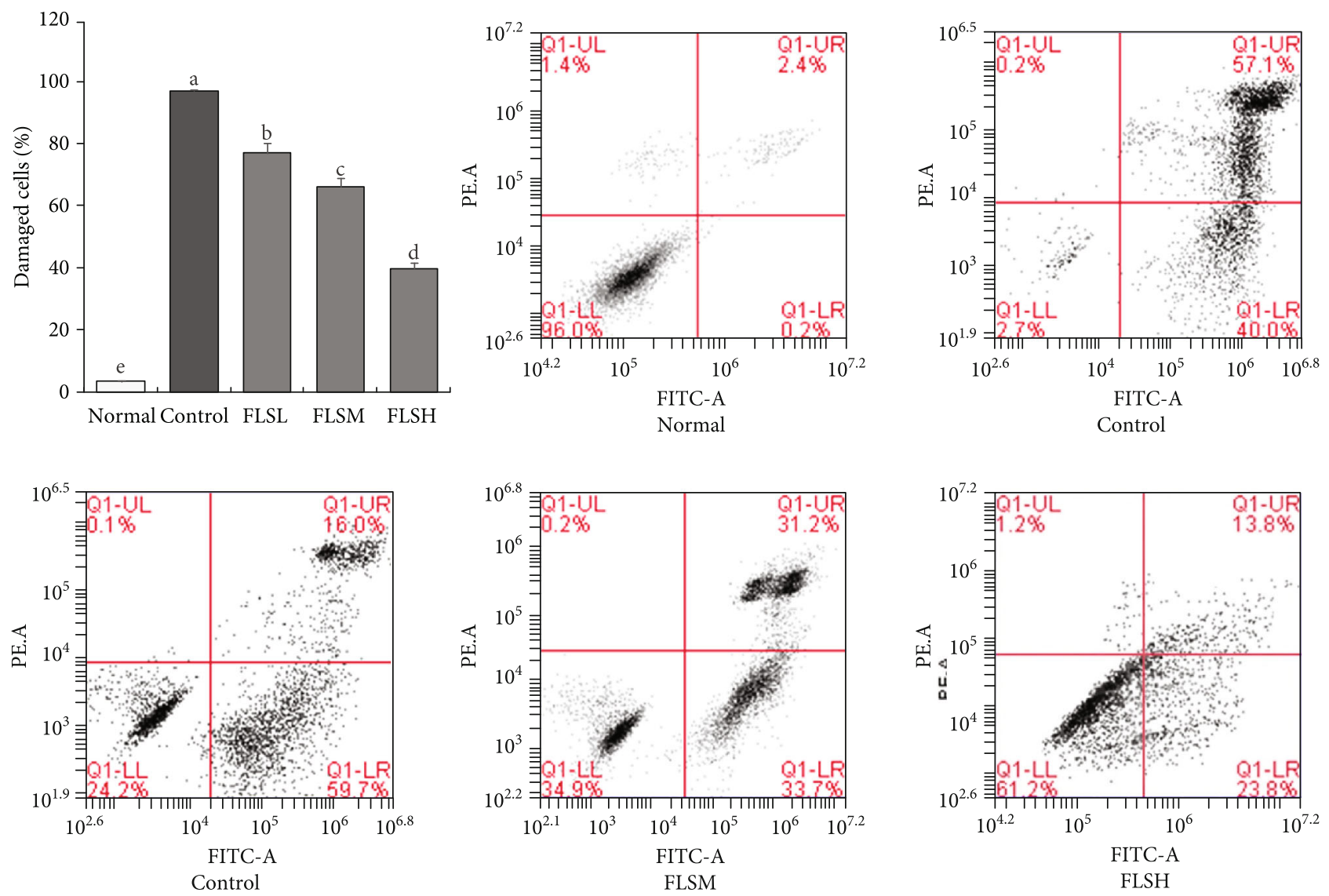

Figure 3: Inhibitory apoptosis effect of flavonoids of lemon seeds (FLS) on $\mathrm{H}_{2} \mathrm{O}_{2}$-damaged human embryonic kidney $293 \mathrm{~T}$ cells. ${ }^{\mathrm{a}-\mathrm{e}} \mathrm{Mean}$ values with different letters over the bar are significantly different $(P<0.05)$ according to Tukey's honestly significant difference. Normal: untreated HEK 293T cells; FLSL: $50 \mu \mathrm{g} / \mathrm{mL}$ of FLS-treated HEK 293T cells; FLSM: $100 \mu \mathrm{g} / \mathrm{mL}$ of FLS-treated HEK 293T cells; FLSH: $150 \mu \mathrm{g} / \mathrm{mL}$ of FLS-treated HEK $293 \mathrm{~T}$ cells.

with $50 \mu \mathrm{g} / \mathrm{mL}, 100 \mu \mathrm{g} / \mathrm{mL}$, and $150 \mu \mathrm{g} / \mathrm{mL}$ FLS extracts were significantly improved, and the survival rate of the cells treated with high concentration $(150 \mu \mathrm{g} / \mathrm{mL})$ was $89.2 \%$, with more significant effect $(P<0.05)$.

3.3. Inhibition of FLS on Damage of HEK 293T Cells Induced by $\mathrm{H}_{2} \mathrm{O}_{2}$. In Figure 3, compared with normal cells, severe damage (damaged and apoptosis cells) is shown in HEK $293 \mathrm{~T}$ cells injured by $\mathrm{H}_{2} \mathrm{O}_{2}$ (97.1\% damaged and apoptosis cells in the control group). After treatment with $50 \mu \mathrm{g} / \mathrm{mL}$ (77.1\% damaged and apoptosis cells), $100 \mu \mathrm{g} / \mathrm{mL}(66.2 \%$ damaged and apoptosis cells), and $150 \mu \mathrm{g} / \mathrm{mL}$ FLS $(39.8 \%$ damaged and apoptosis cells) extracts, cell damage is significantly inhibited $(P<0.05)$, and the inhibitory effect is better with increased FLS concentration.

3.4. Changes in MDA, SOD, GSH, GSH-Px, and CAT Levels in HEK 293 T Cells Treated with FLS. As shown in Figure 4, the MDA content of HEK 293T cells treated by $\mathrm{H}_{2} \mathrm{O}_{2}$ $(0.3 \mathrm{mmol} / \mathrm{L})$ for $4 \mathrm{~h}$ is significantly higher than that in normal cells, but the OD, GSH, GSH-Px, and CAT levels are significantly lower. After being treated with FLS at different concentrations $(50 \mu \mathrm{g} / \mathrm{mL}, 100 \mu \mathrm{g} / \mathrm{mL}$, and $150 \mu \mathrm{g} / \mathrm{mL})$, the MDA content is significantly lower $(P<0.05)$, but the SOD, GSH, GSH-Px, and CAT levels are significantly higher $(P<0.05)$. The effect of $150 \mu \mathrm{g} / \mathrm{mL}$ FLS treatment is the most significant.

3.5. Effects of FLS on Clone Formation in Damaged HEK 293T Cells. As shown in Table 2, compared to the normal HEK 293T cells, $\mathrm{H}_{2} \mathrm{O}_{2}$ had a significant effect $(P<0.05)$ on cell clone formation of HEK $293 \mathrm{~T}$ cells, and the control group had the least number of HEK 293T cell clones. FLS could significantly $(P<0.05)$ inhibit the decrease of clonal formation caused by $\mathrm{H}_{2} \mathrm{O}_{2}$, and with the increase of FLS concentration, the inhibition effect was stronger.

3.6. Effects of FLS on Expressions of SOD, CAT, GSH, and GSH-PX in Damaged HEK $293 T$ Cells. As shown in Figure 5, after $\mathrm{H}_{2} \mathrm{O}_{2}$-induced injury $(0.3 \mathrm{mmol} / \mathrm{L})$, the mRNA expressions of SOD, CAT, GSH, and GSH-Px in HEK 293T cells and the protein expressions of SOD1, SOD2, CAT, and GSH are significantly decreased. SOD, CAT, GSH, and GSH-Px expressions in the damaged cells are significantly increased after treatment with FLS $(P<0.05)$, which is consistent with the results of the kit test. FLS could increase the SOD, CAT, GSH, and GSHPx levels as it was determined using a kit to determine the expression in damaged HEK 293T cells using qPCR and Western blot assays. 

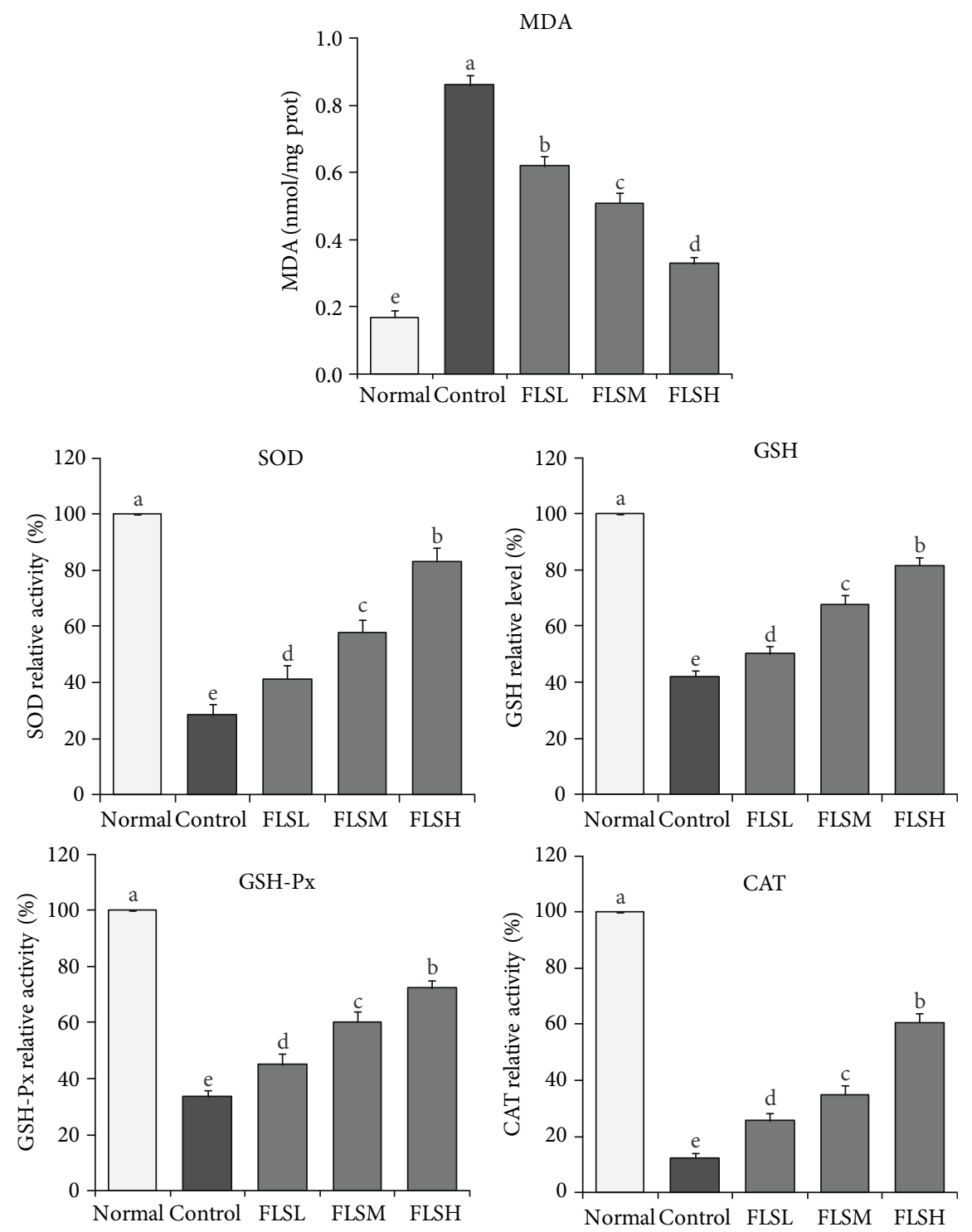

FIGURE 4: Effect of flavonoids of lemon seeds (FLS) on the levels of MDA, SOD, GSH, GSH-Px, and CAT in human embryonic kidney 293T cells exposed to $\mathrm{H}_{2} \mathrm{O}_{2} \cdot{ }^{\text {a-e }}$ Mean values with different letters over the bar are significantly different $(P<0.05)$ according to Tukey's honestly significant difference. Normal: untreated HEK 293T cells; FLSL: $50 \mu \mathrm{g} / \mathrm{mL}$ of FLS-treated HEK 293T cells; FLSM: $100 \mu \mathrm{g} / \mathrm{mL}$ of FLStreated HEK 293T cells; FLSH: $150 \mu \mathrm{g} / \mathrm{mL}$ of FLS-treated HEK 293T cells.

TABLE 2: Effects of flavonoids of lemon seeds (FLS) on clone formation in $\mathrm{H}_{2} \mathrm{O}_{2}$ induced damage human embryonic kidney 293 T cells.

\begin{tabular}{lcc}
\hline Group & Number of clones & Clonogenic rate (\%) \\
\hline Normal & $48.39 \pm 4.57^{\mathrm{a}}$ & $100.00 \pm 0.00^{\mathrm{a}}$ \\
Control & $10.32 \pm 3.02^{\mathrm{e}}$ & $21.33 \pm 2.77^{\mathrm{e}}$ \\
FLSL & $20.59 \pm 3.80^{\mathrm{d}}$ & $42.55 \pm 3.12^{\mathrm{d}}$ \\
FLSM & $31.14 \pm 4.11^{\mathrm{c}}$ & $64.35 \pm 4.83^{\mathrm{c}}$ \\
FLSH & $39.67 \pm 2.03^{\mathrm{b}}$ & $82.00 \pm 2.46^{\mathrm{b}}$ \\
\hline
\end{tabular}

Values presented are the mean \pm standard deviation ( $N=6$ /group). ${ }^{\mathrm{a}-\mathrm{e}}$ Mean values with different letters over the same column are significantly different $(P<0.05)$ according to Tukey's honestly significant difference. Normal: untreated HEK 293T cells; FLSL: $50 \mu \mathrm{g} / \mathrm{mL}$ of FLS-treated HEK 293T cells; FLSM: $100 \mu \mathrm{g} / \mathrm{mL}$ of FLS-treated HEK 293T cells; FLSH: $150 \mu \mathrm{g} / \mathrm{mL}$ of FLS-treated HEK 293T cells.
3.7. Determination of FLS by HPLC. As shown in Figure 6, FLS contain six compounds, including gallocatechin, caffeic acid, epicatechin, vitexin, quercetin, and hesperidin. Their peak retention time on the liquid chromatogram was $5.664 \mathrm{~min}, 9.715 \mathrm{~min}, 10.611 \mathrm{~min}, 20.442 \mathrm{~min}, 25.017 \mathrm{~min}$, and $31.010 \mathrm{~min}$, respectively. The contents of the six components in the FLS were $18.304 \mathrm{mg} / \mathrm{g}, 37.294 \mathrm{mg} / \mathrm{g}, 25.080 \mathrm{mg} / \mathrm{g}$, $108.539 \mathrm{mg} / \mathrm{g}, 334.585 \mathrm{mg} / \mathrm{g}$, and $145.983 \mathrm{mg} / \mathrm{g}$, respectively.

\section{Discussion}

The damage caused by oxidative stress affected the proliferation of normal cells and led to cell death and decline in the proliferation of cells [16]. Thus, FLS can inhibit the decreased proliferation of HEK $293 \mathrm{~T}$ cells induced by $\mathrm{H}_{2} \mathrm{O}_{2}$ and protect normal cell proliferation. Oxidative stress can damage cells, 

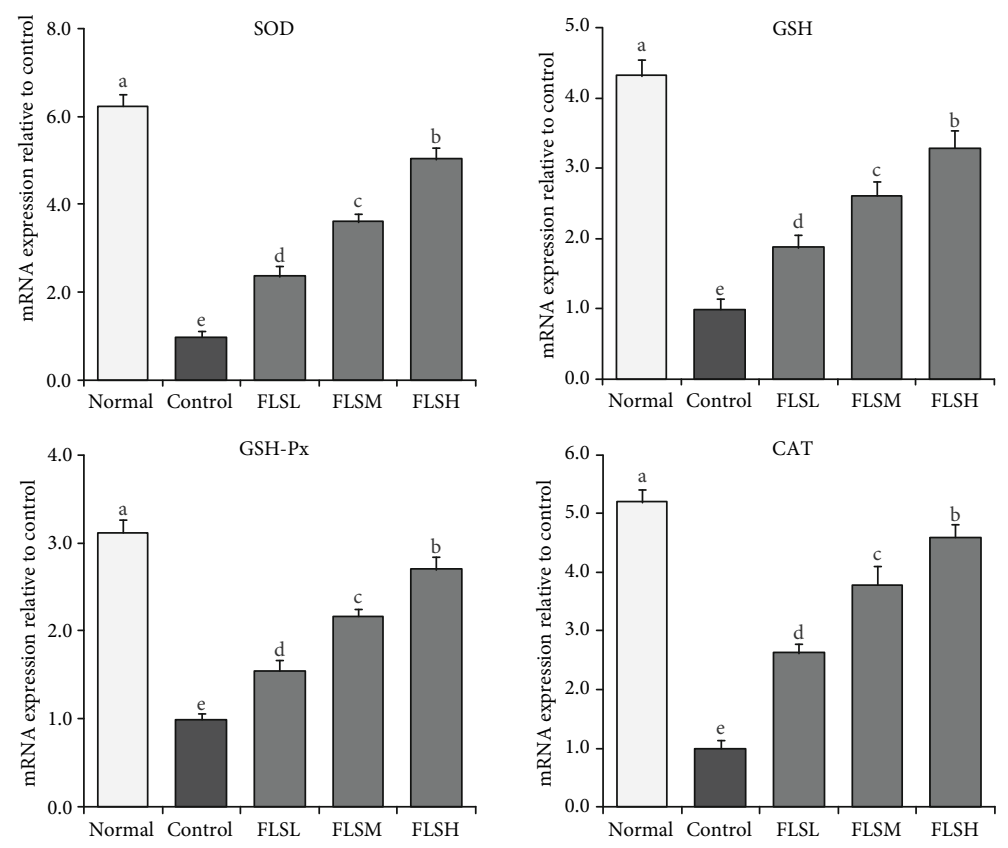

(a)
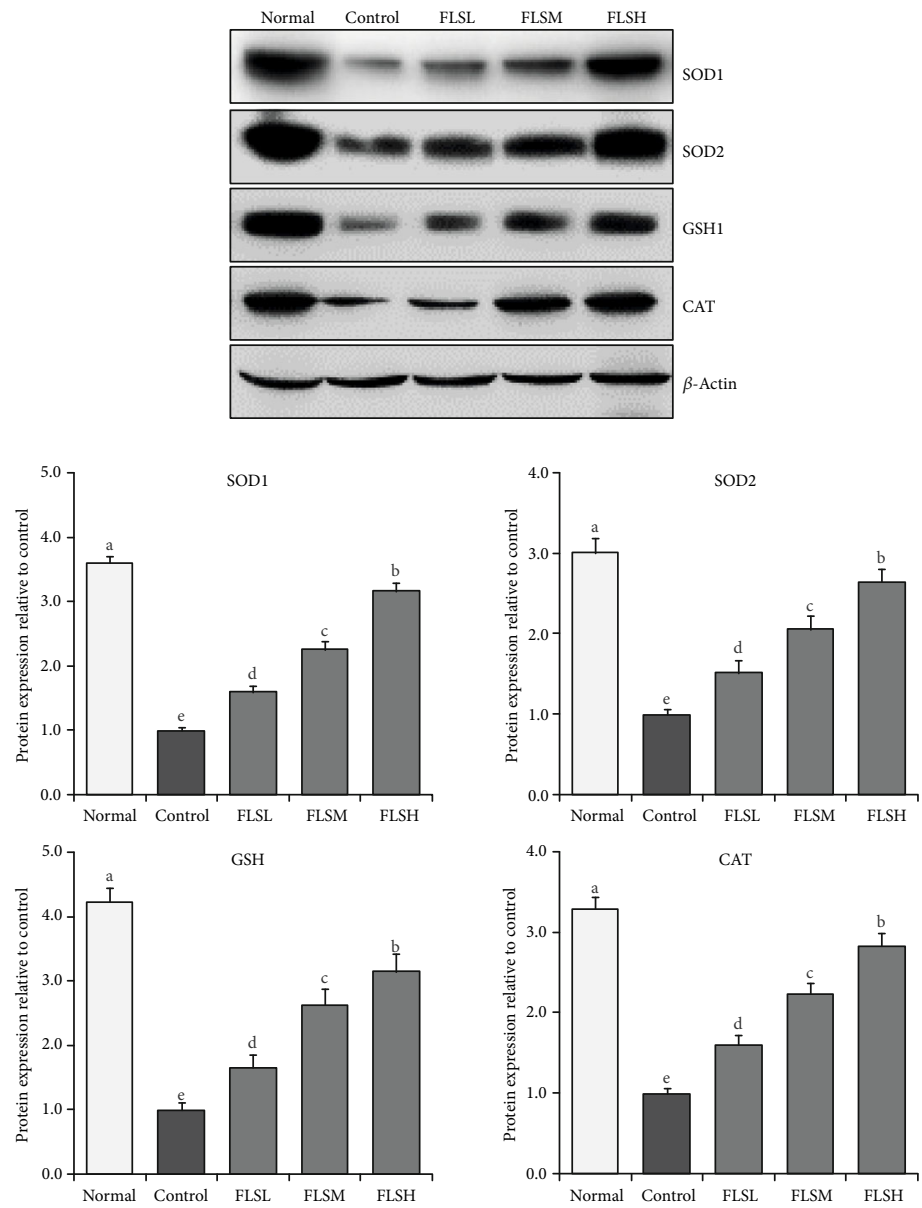

(b)

FIGURE 5: mRNA (a) and protein (b) expression of flavonoids of lemon seeds (FLS) on $\mathrm{H}_{2} \mathrm{O}_{2}$-damaged human embryonic kidney 293T cells. ${ }^{a-e}$ Mean values with different letters over the bar are significantly different $(P<0.05)$ according to Tukey's honestly significant difference. Normal: untreated HEK 293T cells; FLSL: $50 \mu \mathrm{g} / \mathrm{mL}$ of FLS-treated HEK 293T cells; FLSM: $100 \mu \mathrm{g} / \mathrm{mL}$ of FLS-treated HEK 293T cells; FLSH: $150 \mu \mathrm{g} / \mathrm{mL}$ of FLS-treated HEK 293T cells. 


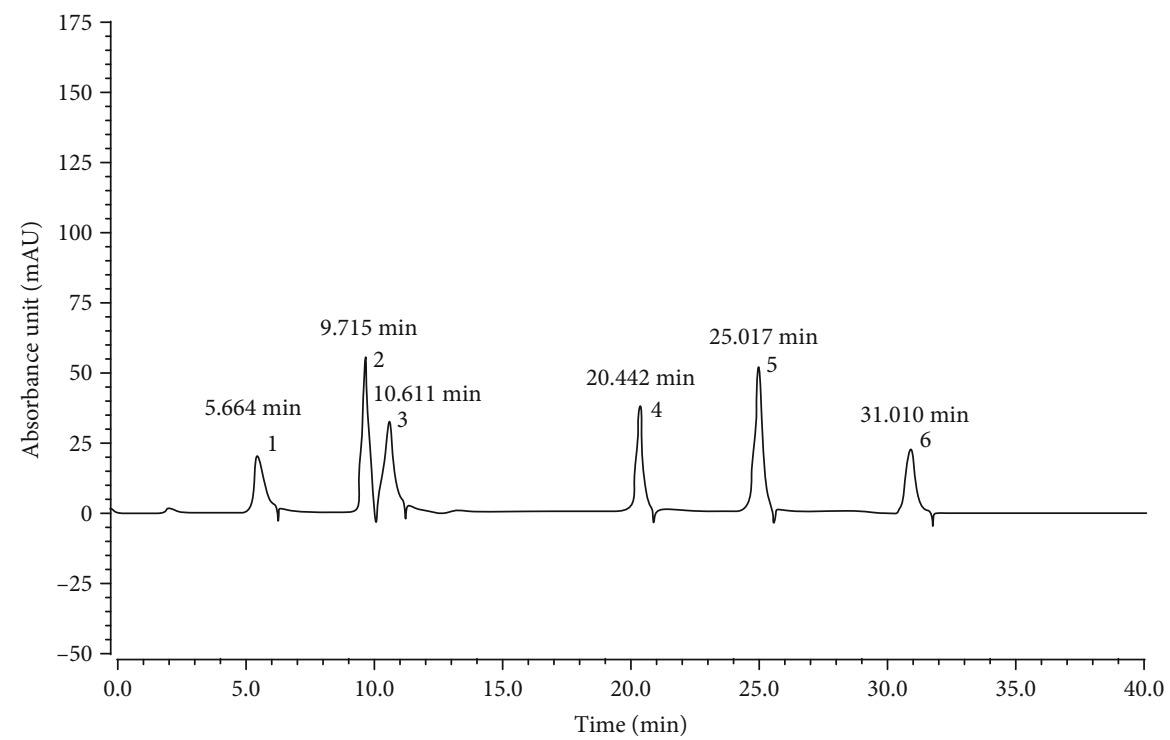<smiles>Oc1cc(O)c2c(c1)OC(c1cc(O)c(O)c(O)c1)[C@H](O)C2</smiles>

(a)

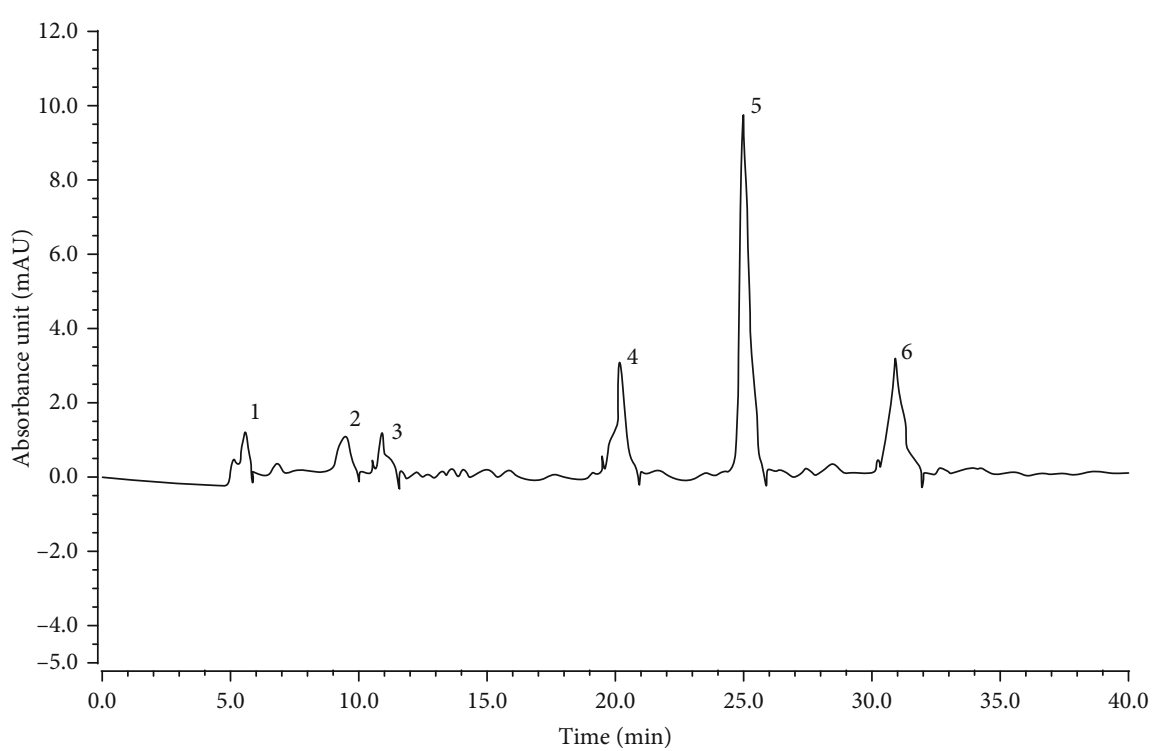

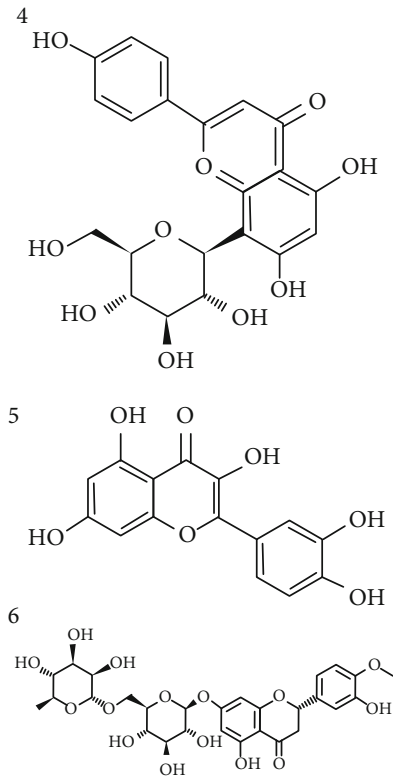

(b)

FIGURE 6: Flavonoid extract constituents of lemon seeds: (a) standard chromatograms; (b) flavonoids of lemon seed chromatograms. 1: gallocatechin; 2: caffeic acid; 3: epicatechin; 4: vitexin; 5: quercetin; 6: hesperidin.

cause apoptosis, promote death of normal cells, and effectively protect normal cells by reducing the degree of apoptosis of oxidation-damaged cells [17]. When FLS and $\mathrm{H}_{2} \mathrm{O}_{2}$ are added to the cultured cells at the same time, FLS can react directly with $\mathrm{H}_{2} \mathrm{O}_{2}$, reducing the amount of $\mathrm{H}_{2} \mathrm{O}_{2}$ that can damage the cells, thus playing a stronger role than the intervention of adding the FLS after $\mathrm{H}_{2} \mathrm{O}_{2}$ first damages the cells. Therefore, FLS can effectively prevent cell apoptosis caused by oxidative stress and protect normal cells.

MDA released from cell membrane reacts with protein and nucleic acid, causes crosslinking polymerization, and inhibits protein synthesis, mainly by damaging membrane structure and function, changing its permeability, thus affecting biochemical reaction in the normal body [18].
Therefore, MDA content can reflect the degree of lipid peroxidation and cell damage. The intake of appropriate antioxidant substances can reduce the degree of ROSinduced lipid peroxidation [19]. CAT, SOD, and GSH-Px are important antioxidant enzymes, and GSH is also the one with good antioxidant effect. They can effectively regulate oxidative balance in the body and inhibit the damage caused by oxidative stress [20]. The results of this study indicate that FLS effectively reduce the oxidative stress damage caused by $\mathrm{H}_{2} \mathrm{O}_{2}$ on cells and protect cells.

Clonogenic analysis (colony formation analysis) is an in vitro cell survival test based on the ability of a single cell to grow into a colony, which is essentially an experiment of the "infinite" dividing power of each cell in a population. 
Clonogenic assays can be used to determine the cytotoxicity or the efficacy of drugs or active substances [21]. In this study, we also found that FLS could effectively inhibit the abnormal clone formation of normal cells caused by hydrogen peroxide to achieve the effect of cell protection.

Epigallocatechin, which is a compound derived from plants, has certain antioxidant activity [22]. Caffeic acid has a wide range of antibacterial and antiviral activities [23] and has been proven to inhibit the formation of lipid peroxides in the murine brain homogenate [24]. Epicatechin can function as antioxidants, scavenging free radicals, strengthening metabolism, and regulating immunity and antitumor activity. Its antioxidant capacity is considered to be the combination of phenolic hydroxyl groups and free radicals in molecules to scavenge free radicals [25]. The main function of vitexin is to promote blood circulation, remove blood stasis, regulate qi, and dredge blood vessels. Vitexin is also a natural drug component for cancer prevention and antitumor activity [26]. Quercetin, which is widely found in plants, has been shown to have antioxidant effect, anti-inflammatory effect, antiviral effect, antitumor activity, antiatherosclerosis effect, neuroprotective effect, blood pressure lowering efficacy, and other biological activities [27]. Hesperidin, which is anti-inflammatory and antiviral with antibacterial effects, is used for treating hypertension and myocardial infarction [28]. These six substances are all compounds with effective biological activity. The normal protective effect of FLS is attributed to the biological activity of these chemicals, and the mixture of these compounds may produce an improved combined effect, which warrants additional investigation.

\section{Conclusions}

In this study, in vitro experiments were conducted to evaluate the effect of FLS on the improvement in cell level and potential active compounds under oxidative damage. The results of in vitro experiments showed that FLS demonstrated beneficial effects on the oxidative cell damage, which avoided cell death caused by oxidative stress, inhibited cell apoptosis caused by oxidative damage, and enhanced the antioxidant enzymes in cells to resist oxidative stress. The component analysis results indicated that the active compounds contained in FLS had multiple biological activities, and that their combination showed an inhibitory effect on oxidative cell damage. However, this study only preliminarily investigated antioxidant activity and improvement on the oxidative damage of FLS from lemon seeds in vitro. The mechanism of antioxidant protection in vivo requires additional exploration.

\section{Data Availability}

No data were used to support this study.

\section{Conflicts of Interest}

The authors declare that they have no potential conflicts of interest to disclose.

\section{Authors' Contributions}

Dingyi Yang performed the majority of the experiments and wrote the manuscript; Yong Jiang, Yuqing Wang, Qianqian Luo, Xin Zhao, and Ruokun Yi contributed to the data analysis; and Xin Zhang designed and supervised the study and read the final manuscript.

\section{Acknowledgments}

This study was supported, in part, by the Science and Technology Research Project of Chongqing Education Commission (KJQN201900104), the Chongqing Natural Science Foundation Project (cstc2019jcyj-msxmX0648), the Chongqing Science and Technology Innovation Guidance Project Led by Academician (cstc2017jcyj-yszx0001), the Chongqing Major Disease Prevention and Control Technology Project (2019ZX002) and the Construction of Scientific Research Platform of Chongqing Collaborative Innovation Center for Functional Food at the Chongqing University of Education, China.

\section{References}

[1] S. W. Zhang, G. X. Huang, F. Ding, X. H. He, and J. C. Pan, "Mechanism of seedlessness in a new lemon cultivar "Xiangshui" (Citrus limon (L.) Burm. F)," Sexual Plant Reproduction, vol. 25, no. 4, pp. 337-345, 2012.

[2] D. M. M. Luzia and N. Jorge, "Antioxidant activity of lemon seed extract (Citrus limon) added to soybean oil in accelerated incubator-storage test," Química Nova, vol. 32, no. 4, pp. 946949, 2008.

[3] D. M. Luzia and N. Jorge, "Oxidative stability and alphatocopherol retention in soybean oil with lemon seed extract (Citrus limon) under thermoxidation," Natural Product Communications, vol. 4, no. 11, pp. 1553-1556, 2009.

[4] J. Kim, G. K. Jayaprakasha, R. M. Uckoo, and B. S. Patil, "Evaluation of chemopreventive and cytotoxic effect of lemon seed extracts on human breast cancer (MCF-7) cells," Food and Chemical Toxicology, vol. 50, no. 2, pp. 423-430, 2012.

[5] K. P. Poulianiti, A. Kaltsatou, G. I. Mitrou et al., "Systemic redox imbalance in chronic kidney disease: a systematic review," Oxidative Medicine and Cellular Longevity, vol. 2016, Article ID 8598253, 19 pages, 2016.

[6] M. Laguerre, J. Lecomte, and P. Villeneuve, "Evaluation of the ability of antioxidants to counteract lipid oxidation: existing methods, new trends and challenges," Progress in Lipid Research, vol. 46, no. 5, pp. 244-282, 2007.

[7] M. Jun, V. Venkataraman, M. Razavian et al., "Antioxidants for chronic kidney disease," Cochrane Database of Systematic Reviews, vol. 10, no. 10, article CD008176, 2012.

[8] V. Danielisová, M. Némethová, M. Gottlieb, and J. Burda, "The changes in endogenous antioxidant enzyme activity after postconditioning," Cellular and Molecular Neurobiology, vol. 26, no. 7-8, pp. 1181-1191, 2006.

[9] D. Shanmugasundaram, A. Duraiswamy, A. Viswanathan, C. S. Sasikumar, S. M. Cherian, and K. M. Cherian, "Development of an antidiabetic polyherbal formulation (ADPHF6) and assessment of its antioxidant activity against ROSinduced damage in pUC19 and human lymphocytes-an 
in vitro study," Journal of Complementary and Integrative Medicine, vol. 13, no. 3, pp. 267-274, 2016.

[10] Y. H. Chen, X. Q. Zhu, X. Z. Zheng et al., "Study on mechanism of BMSCs on aging 293T cells," Medical Journal of National Defending Forces in Southwest China, vol. 29, no. 7, pp. 727-730, 2019.

[11] J. L. Meng, Y. C. Xu, X. F. Shen et al., "Construction of human PKD2 lentivirus to rectify polycystin-2 expression and Wnt/ $\beta$ catenin signaling pathways in the Pkd2-null cell lines," Chinese Journal of Urology, vol. 39, no. 1, pp. 62-68, 2018.

[12] X. X. Zhang, X. D. Zhang, X. C. Yang, B. L. Liu, H. Yuan, and H. T. Cheng, "Protective effect of high expression of Klotho gene on kidney of rats with diabetic nephropathy," Chinese Journal of Biologicals, vol. 27, no. 8, pp. 1015-1020, 2014.

[13] G. Lv, P. G. Du, D. Tian et al., "The effect of GHGKHKNK octapeptide on clone formation, adhesion and in vitro invasion of carcinoma," Chinese Journal of Gerontology, vol. 28, no. 15, pp. 1470-1472, 2008.

[14] Y. Zhou, F. Tan, C. Li et al., "White peony (fermented Camellia sinensis) polyphenols help prevent alcoholic liver injury via antioxidation," Antioxidants, vol. 8, no. 11, p. 524, 2019.

[15] B. Liu, J. Zhang, P. Sun, R. Yi, X. Han, and X. Zhao, "Raw bowl tea (Tuocha) polyphenol prevention of nonalcoholic fatty liver disease by regulating intestinal function in mice," Biomolecules, vol. 9, no. 9, p. 435, 2019.

[16] H. Kim, K. I. Lee, M. Jang et al., "Conessine interferes with oxidative stress-induced C2C12 myoblast cell death through inhibition of autophagic flux," PLoS One, vol. 11, no. 6, article e0157096, 2016.

[17] J. Huang, C. Zhou, J. He, Z. Hu, W. C. Guan, and S. H. Liu, "Protective effect of reduced glutathione C60 derivative against hydrogen peroxide-induced apoptosis in HEK 293T cells," Journal of Huazhong University of Science and Technology (Medical Sciences), vol. 36, no. 3, pp. 356-363, 2016.

[18] L. J. Marnett, "Lipid peroxidation-DNA damage by malondialdehyde," Mutation Research, vol. 424, no. 1-2, pp. 83-95, 1999.

[19] C. X. Ni, H. Gong, Y. Liu, Y. Qi, C. L. Jiang, and J. P. Zhang, "Green tea consumption and the risk of liver cancer: a metaanalysis," Nutrition and Cancer, vol. 69, no. 2, pp. 211-220, 2017.

[20] C. Bowler, M. V. Montagu, and D. Inze, "Superoxide dismutase and stress tolerance," Annual Review of Plant Biology, vol. 43, no. 1, pp. 83-116, 1992.

[21] N. A. Franken, H. M. Rodermond, J. Stap, J. Haveman, and C. van Bree, "Clonogenic assay of cells in vitro," Nature Protocols, vol. 1, no. 5, pp. 2315-2319, 2006.

[22] L. C. Vázquez Cisneros, P. López-Uriarte, A. López-Espinoza, M. Navarro Meza, A. C. Espinoza-Gallardo, and M. B. Guzmán Aburto, "Effects of green tea and its epigallocatechin (EGCG) content on body weight and fat mass in humans: a systematic review," Nutricion Hospitalaria, vol. 34, no. 3, pp. 731-737, 2017.

[23] M. F. Tolba, H. A. Omar, S. S. Azab, A. E. Khalifa, A. B. AbdelNaim, and S. Z. Abdel-Rahman, "Caffeic acid phenethyl ester: a review of its antioxidant activity, protective effects against ischemia-reperfusion injury and drug adverse reactions," Critical Reviews in Food Science and Nutrition, vol. 56, no. 13, pp. 2183-2190, 2016.

[24] S. Basu Mallik, J. Mudgal, M. Nampoothiri et al., "Caffeic acid attenuates lipopolysaccharide-induced sickness behaviour and neuroinflammation in mice," Neuroscience Letters, vol. 632, pp. 218-223, 2016.

[25] S. Cheng, L. Ding, Y. Zhen et al., "Progress in studies on the antimutagenicity and anticarcinogenicity of green tea epicatechins," Chinese Medical Sciences Journal, vol. 6, no. 4, pp. 233238, 1991.

[26] B. A. Nikfarjam, F. Hajiali, M. Adineh, and M. Nassiri-Asl, "Anti-inflammatory effects of quercetin and vitexin on activated human peripheral blood neutrophils: the effects of quercetin and vitexin on human neutrophils," Journal of Pharmacopuncture, vol. 20, no. 2, pp. 127-131, 2017.

[27] V. Karuppagounder, S. Arumugam, R. A. Thandavarayan, R. Sreedhar, V. V. Giridharan, and K. Watanabe, "Molecular targets of quercetin with anti-inflammatory properties in atopic dermatitis," Drug Discovery Today, vol. 21, no. 4, pp. 632-639, 2016.

[28] W. S. Park, M. S. Park, S. W. Kang et al., "Hesperidin shows protective effects on renal function in ischemia-induced acute kidney injury (Sprague-Dawley rats)," Transplantation Proceedings, vol. 51, no. 8, pp. 2838-2841, 2019. 